\title{
Tafsir Atas Budaya Khatm Al-Qur'ān \\ Di Pondok Pesantren Sunan Pandanaran Yogyakarta
}

\author{
Tinggal Purwanto \\ IAIN Syaikh Abdurrahman Siddik Bangka Belitung \\ tinggalpurwanto81@gmail.com
}

\begin{abstract}
This article reveals the phenomenon of Khatm Al-Qur'än culture in Pondok Pesantren Sunan Pandanaran (PPSPA) Yogyakarta. The author examines how Al-Qur'an's Khatm culture is in PPSPA, what are the variations, as well as how the usage of Al-Qur'an's Khatm by the PPSPA community. This article is to find that Al-Qur'an Khatm is not only a complete activity to read alQur'an by the Muslim community. Khatm Al-Qur'ān in its development is done with various varians and different purposes so it is interesting to be examined more deeply. With the perspective of cultural interpretation, the use and understanding of the Muslim community towards the Qur'an Khatm is varied. This diversity looks at the cultural behavior of its community can be interpreted with its various dimensions: spiritual dimension, individual dimension, and social dimension.
\end{abstract}

Keywords: Khatm Al-Qur'ān, Spiritual Dimensions, Individual dimensions, Social Dimensions.

\begin{abstract}
Abstrak: Artikel ini mengungkap fenomena Budaya Khatm Al-Qur'an di Pondok Pesantren Sunan Pandanaran (PPSPA) Yogyakarta. Penulis mengkaji bagaimana budaya Khatm Al-Qur'ān di PPSPA, apa saja variannya, serta bagaimana pemaknaan Khatm Al-Qur'ān oleh komunitas PPSPA. Artikel ini mendapatkan bahwa Khatm Al-Qur'ān tidak hanya sebatas aktivitas menamatkan membaca al-Qur'an yang dilakukan oleh komunitas muslim. Khatm Al-Qur'ān pada perkembangannya dilakukan dengan berbagai variandan tujuan yang berbeda sehingga menarik untuk dikaji lebih mendalam. Dengan perspektif tafsir kebudayaan, pemaknaan dan pemahaman komunitas muslim terhadap Khatm Al-Qur'ān tersebut menjadi beragam. Keragaman ini tampak pada perilaku budaya komunitasnya bisa ditafsirkan dengan beragam dimensinya, yakni: dimensi spiritual, dimensi individual, dan dimensi sosial.
\end{abstract}

Kata Kunci: Khatm Al-Qur'ān, Dimensi Spiritual, dimensi individual, Dimensi Sosial. 


\section{Pendahuluan}

Al-Qur'an diyakini memberikan pengaruh yang luar biasa dalam kehidupan masyarakat muslim. Hal ini dapat dilihat dari banyaknya norma, aturan, ataupun kultur sosial-budaya yang dibangun dalam sebuah interaksi yang harmonis antara umat Islam dengan al-Qur'an. Semuanya senantiasa berkembang seiring perkembangan zaman. Beberapa praktik budaya keagamaan yang didasarkan atas pemahamannya terhadap alQur'an ini, secara umum, ditradisikan oleh mayoritas muslim. Meski ada beberapa budaya yang secara spesifik hanya terdapat di daerah tertentu. Meminjam pemahaman Saeed, benang merah pada semua budaya yang ada ini adalah sebagai wujud pengaguman dan penghormatan terhadap alQur'an sebagai firman Tuhan yang terjaga kemurniannya. ${ }^{1}$

Hadirnya budaya akibat adanya interaksi antara komunitas muslim dengan kitab sucinya, Al-Qur'an, senantiasa mengalami perkembangan yang dinamis. Berinteraksi dengan al-Qur'an merupakan salah satu pengalaman beragama yang berharga bagi setiap muslim. Pengalaman berinteraksi dengan al-Qur'an terekspresikan secara spiritual maupun secara emosional, baik secara lisan, tulisan, maupun praktik keagamaan tertentu. Dari interaksi-interaksi tersebut kemudian membentuk fenomenafenomena budaya yang berbasiskan alQur'an.

Eksistensi al-Qur'an yang șāliḥ li kulli zamān wa makān selalu menarik untuk diteliti, dikaji dan ditelaah. Munculnya kajian living Qur'an melahirkan dengan budaya alQur'an yang menyebar di setiap daerah. Munculnya aktivitas, rutinitas bahkan menjadi

\footnotetext{
1 Abdullah Saeed, The Qur'an: An Introduction (London and New York: Routledge, 2008). p.84
}

sebuah tradisi yang turun temurun di kalangan umat Islam, telah melahirkan budaya-budaya baru yang mendapat banyak respons di masyarakat. Berbagai pendapat, tafsiran, dan sejenisnya, terhadap perilaku masyarakat dalam merespons al-Qur'an, baik positif maupun negatif, menarik sekali untuk dikaji dengan paradigma tafsir kebudayaan.

Khatm al-Qur'ān salah satu dari sekian banyak fenomena budaya umat Islam dalam menghidupkan atau menghadirkan al-Qur'an (living Qur'an) dalam kehidupan sehari-hari umat Islam. Beberapa riset pernah mengemukakan budaya khatm al-Qur'ān di beberapa daerah, misalnya Tradisi Mappanre Temme' di Masyarakat Bugis Sulawesi Selatan, ${ }^{2}$ tradisi Khatam Kaji di masyarakat Minang, ${ }^{3}$ Budaya khatm al-Qur'ān ini akan lebih tampak sebagai sebuah budaya yang rutin dilaksanakan di pondok-pondok pesantren, salah satunya di Pondok Pesantren Sunan Pandanaran (PPSPA) Yogyakarta. ${ }^{4}$ Di PPSPA, khatm al-Qur'ān yang awal mulanya merupakan aktivitas menamatkan membaca al-Qur'an baik bi al-nadarī (melihat teks) maupun bi al-hifẓī (menghafal) atau bi alghaib (tanpa melihat teks) yang ditutup dengan doa khatm al-Qur'ān, ternyata dalam perkembangan selanjutnya dipahami beragam oleh para penganutnya yang mengikuti tradisi tersebut. Fenomena ini menjadi layak untuk

${ }^{2}$ Chaerul Mundzir, "Nilai-Nilai Sosial Dalam Tradisi Mappanre Temme Di Kecamatan Tanete Rilau, Kabupaten Barru," Rihlah: Jurnal Sejarah Dan Kebudayaan 1, no. 2 (2014): 69-80.

3 Gusnanda, "Katam Kaji: Resepsi Al-Qurán Masyarakat Pauh Kamang Mudiak Kabupaten Agam," Mashdar: Jurnal Studi Qur'an Dan Hadis 1, no. 1 (2019): 67-82.

4 'Nama 'Sunan Pandan Aran' diambil Dari Silsilah Keturunan KH. Mufid Mas'ud. Beliau Adalah Keturunan Ke-10 Dari Ki Ageng Sunan Pandan Aran, Salah Satu Santri Dari Sunan Kalijaga," Suara Pandanaran; Majalah Pesantren, September 2005, I edition. p.6-8 
diteliti, ditafsirkan, dan dimaknai ulang dengan paradigma tafsir kebudayaan sehingga dapat ditemukan kebaharuan budaya yang dihasilkan dari budaya living Qur'an tersebut.

Term paradigma dalam tulisan ini merujuk kepada term yang disampaikan oleh Heddy Ahimsa-Putra dalam artikelnya berjudul "Paradigma Ilmu Sosial-Budaya: Sebuah Pandangan”. Menurut Ahimsa-Putra, paradigma dapat didefinisikan sebagai seperangkat konsep yang berhubungan satu sama lain secara logis membentuk sebuah kerangka pemikiran yang berfungsi untuk memahami, menafsirkan dan menjelaskan kenyataan dan atau masalah yang dihadapi. ${ }^{5}$

Term tafsir, secara bahasa berasal dari bahasa Arab dan merupakan bentuk masdar dari kata fasara serta terdiri dari huruf $f a$, sin, dan $r a$ ' itu berarti keadaan jelas (nyata dan terang) dan memberikan penjelasan. Merujuk kepada pendapat Ibn Manzhur dalam Lisān al- 'Arāb, pengertian "tafsir" secara bahasa adalah "kashf al-mughattā" yang berarti membuka sesuatu yang tertutup. ${ }^{6}$ Dalam hal ini, tafsir dipahami sebagai penjelasan maksud yang sukar dari suatu lafal. Sementara itu al-Dhahabī mendefinisikan tafsir dengan "al-Idhah wa al-Tabyin" yang berarti penjelasan dan keterangan. ${ }^{7}$ Dalam kamus Bahasa Indonesia, kata tafsir diartikan dengan "keterangan atau penjelasan tentang ayat-ayat al-Qur'an atau kitab suci lain sehingga lebih jelas maksudnya". ${ }^{8}$ Dari definisi ini dipahami bahwa tafsir tidak harus

5 Heddy Shri Ahimsa-Putra, "Fenomenologi Agama: Pendekatan Fenomenologi Untuk Memahami Agama," Walisongo 20, no. 2 (2012): 271-304.

6 Ibn Manzhur, Lisan Al-'Arab (Beirut: Dar Shadir, n.d.). 55.

7 Al-Dzahabi, Al-Tafsir Wa Al-Mufassirun, 1st ed. (Kairo: dar al-Kutub al-Haditsat, 1991), 13.

8 Kamus Besar Bahasa Indonesia, "KBBI Daring Kemdikbud," 2018, https://kbbi. kemdikbud. go. id. selalu terkait dengan al-Qur'an, tetapi bisa juga untuk menafsirkan yang lain, salah satunya menafsirkan budaya atau tafsir kebudayaan.

Adapun dalam menjelaskan tafsir kebudayaan ini, artikel ini akan lebih banyak mengambil pendapat-pendapat Clifford Geertz, utamanya pada bagian I, sub judul "Lukisan Mendalam: Menuju Sebuah Teori Interpretatif tentang Kebudayaan". Hal ini dilakukan, mengingat, Geertz adalah antropolog yang paling banyak menggunakan teori ini dalam kajian tafsir kebudayaan (antropologi). Kebudayaan sebagaimana didefinisikan Clyde Kluckhohn dalam bukunya Mirror for Man, sebagaimana dikutip Clifford Geertz sebagai:

(1) "keseluruhan cara hidup masyarakat"; (2) "warisan sosial yang diperoleh individu dari kelompoknya"; (3) "suatu cara berpikir, merasa dan percaya"; (4) suatu abstraksi dari tingkah laku"; (5) suatu teori pada pihak antropolog tentang cara suatu kelompok masyarakat nyatanya bertingkah laku; (6) suatu "gudang untuk mengumpulkan hasil belajar"; (7) "seperangkat orientasiorientasi standar pada masalah-masalah yang sedang berlangsung"; (8) "tingkah laku yang dipelajari”; (9) suatu mekanisme untuk penataan tingkah laku yang normatif; (10) "seperangkat teknik untuk menyesuaikan baik dengan lingkungan luar maupun dengan orang-orang lain"; (11) "suatu endapan sejarah". 9

Kebudayaan terkait dengan manusia yang banyak menggunakan simbol-simbol dalam kesehariannya. Clifford Geertz percaya bahwa manusia adalah seekor binatang yang bergantung pada jaringan-jaringan makna

9 Clifford Geertz, Tafsir Kebudayaan, trans. Francisco Budi Hardiman (Yogyakarta: Kanisius, 1992), 4-5 
yang ditenunnya sendiri. Oleh karenanya, Geertz menganggap bahwa kebudayaan sebagai jaring-jaring yang bersifat interpretatif untuk mencari makna dengan cara menguraikan ekspresi-ekspresi sosial tentang permukaan yang penuh teka-teki dari jaring-jaring makna itu. Dengan cara kerja seperti itu, jaring-jaring makna dapat diinterpretasi dengan "lukisan mendalam" sehingga wujud kebudayaan dapat ditemukan makna interpretatifnya yang mendalam. Thick Description (lukisan mendalam) adalah tawaran yang solutif untuk dapat memahami dan menafsirkan hierarkhi yang memiliki jaring-jaring atau lapisan-lapisan strukturstruktur makna yang sangat kompleks. ${ }^{10}$

Menurut Geertz, Kebudayaan itu bersifat publik dan ideasional. Kebudayaan tersusun dari struktur-struktur psikologis yang menjadi sarana individu-individu atau kelompok-kelompok-kelompok individu mengarahkan tingkah laku budaya dalam masyarakat. Dengan interpretasi antropologis, sebuah pembacaan tentang apa yang terjadi, lalu memisahkannya dari apa yang terjadi dapat dilakukan. Interpretasi adalah sesuatu yang lain dari pada tugas yang adamelukiskan segala kata-kata kosong tanpa makna tentang sesuatu. Dari sini kemudian analisis kebudayaan menerka makna-makna, menaksir terkaan-terkaan itu, dan menarik kesimpulan-kesimpulan eksplanatoris dari terkaan-terkaan yang lebih baik, bukannya menemukan benua makna dan memetakan pemandangannya yang tak berwujud itu ${ }^{11}$ dan tidak bersifat prediktif. Dengan hal ini, tugas dan fungsi teori menjadi lebih jelas, yakni sebagai media dalam menafsirkan tindakan simbolis dari perilaku sosial kebudayaan dalam kehidupan manusia, kemudian melukiskannya secara mendalam dengan didukung oleh fakta-fakta yang mendukung pernyataan. $^{12}$

Dalam perspektif penulis, ada beberapa hal yang menyebabkan tafsir kebudayaan layak untuk dijadikan teori dalam memahami budaya living Qur'an di masyarakat. Pertama, Kajian living Qur'an adalah kajian terhadap yang muncul akibat adanya interaksi antara umat Islam dengan kitab sucinya alQur'an sehingga aktivitas-aktivitas living Qur'an yang membentuk budaya khatm alQur'ān di komunitas masyarakat muslim di Pondok Pesantren Sunan Pandanaran menjadi menarik untuk ditafsirkan; Kedua, dengan paradigma tafsir kebudayaan, seorang peneliti memiliki kebebasan mengekspresikan pemikirannya dalam mendeskripsikan secara mendalam budaya yang muncul di sebuah komunitas masyarakat.

Dari uraian di atas, maka penelitian ini menggunakan model penelitian sosial yang bersifat kualitatif dan diharapkan mampu mencerna, mendeskripsikan, menganalisis kemudian menyimpulkan data secara tepat tentang budaya khatm al-Qur'ān di Pondok Pesantren Sunan Pandanaran Yogyakarta dengan perspektif tafsir kebudayaan guna memperoleh makna baru dalam memahami budaya khatm al-Qur'ān dan mengembangkannya secara dialogis sesuai situasi alamiah. ${ }^{13}$ Dengan menggunakan metode kualitatif, Penelitian ini berupaya mengungkap bagaimana budaya khatm alQur'ān di PPSPA. Dalam hal ini, penulis berupaya mendeskripsikan varian khatm alQur'ān di PPSPA dengan pendekatan fenomenologi, selanjutnya dengan pendekatan tafsir kebudayaan, penelitian ini menginterpretasikan budaya khatm al-Qur'ān

\footnotetext{
12 Clifford Geertz., 34-35.

${ }^{13}$ Agus Salim., 4.
}

\footnotetext{
${ }^{10}$ Clifford Geertz, 5-8

${ }^{11}$ Clifford Geertz., 22-25.
} 
di PPSPA. Adapun yang menjadi sumber data penelitian ini adalah informan yang mengetahui betul budaya ini, di antaranya: santri, pengelola, dan pengasuh PPSPA, dan beberapa masyarakat yang terlibat di dalamnya.

\section{Pemaknaan Khatm Al-Qur'ān}

Untuk memahami secara mendalam tentang konsep khatm al-Qur'ān, maka terlebih dahulu perlu dipahami asal-usul dan substansi kata khatm al-Qur'ān dalam studi living Qur'an. Istilah Khatm Al-Qur'ān adalah term telah lama dipergunakan ketika selesai aktivitas setelah menamatkan membaca ataupun menghafalkan al-Qur'an, seperti: Sema'an, muqaddaman dan lain-lain. Secara definitif, pemaknaan term tersebut selain menggunakan beberapa referensi penunjang juga penting untuk mengeksplorasi konsep yang biasa digunakan komunitas pemakainya.

Secara garis besar, pemaknaan kata khatam pada umumnya mengacu kepada dua makna besar, Pertama, berkaitan dengan keabsahan surah. Secara etimologi, kata khatm berasal dari akar kata yang derivasinya membentuk beberapa makna kata. Dalam kamus al-Munjid dan kamus alMunawwir: Kamus Arab Indonesia, kata khatam sendiri memiliki banyak makna, seperti cincin, segel, stempel, madu, lak, cap, lumpur, penghabisan, penutup, selesai, tamat, dan akhir. Akar kata ini kemudian membentuk kata kerja khatama-yakhtimu yang memiliki derivasi makna, di antaranya: membubuhi cap, menyegel, menutup, menjadikan tak dapat memahami, berpaling (kata kiasan) mengakhiri untuk pertama kalinya, mulai sembuh, dan menyelesaikan seluruhnya (sampai tamat). ${ }^{1415}$ Kata alkhatam sendiri dalam Ensiklopedi Islam mempunyai bermacam-macam pengertian yang pada intinya mengandung pengertian yang berkaitan erat dengan keabsahan surah. Khatam berarti "cincin materai" adalah salah satu atribut raja yang merupakan tanda kebesaran dan kemegahannya. Raja membubuhkan khatam itu pada surah kerajaan. Khatam juga berarti, “akhir". Maksudnya, tulisan yang diberi khatam itu benar dan sah atau penulisan surah sudah selesai dan lengkap dengan diberi khatam. Khatam juga berarti wazir. Ini dapat dilihat dari ucapan Harun al-Rasyid ketika hendak mengangkat Ja'far bin Yahya menjadi wazir menggantikan al-Fadal: "Wahai ayahku, aku bermaksud memindahkan khatam dari tangan kananku ke tangan kiriku." Ia membuat kiasan wazir dengan khatam karena pekerjaan memberi khatam adalah salah satu tugas wazir. Penggunaan khatam pernah dilakukan pada masa Nabi Muhammad saw. Diceritakan bahwa ketika Nabi Muhammad saw. hendak mengirim surat ajakan masuk Islam kepada para penguasa lain, kepada Nabi Muhammad saw. dikatakan bahwa para raja non-Arab (ajam) hanya mau menerima surah yang diberi khatam. Maka Nabi Muhammad saw. membuat khatam (cincin stempel) dari bahan perak yang berukirkan: Muhammad Rasulullah. ${ }^{16}$

Makna Kedua, khatam berarti tamat atau selesai aktivitas. Pemaknaan ini tampaknya lebih tepat digunakan dalam tulisan ini. Khataman kemudian lebih dikenal

14 Al-Munjid, Al-Munjid Al-Abjadi, Cet. 37 (Beirut: Dar al-Masyriq, 1998), 168-169.

15 Ahmad Warson Munawwir, Al-Munawwir: Kamus Arab-Indonesia (Surabaya: Pustaka Progresif, 1997), 322.

${ }^{16}$ Nina M. Armando, Ensiklopedi Islam., Jilid 4 (Jakarta: Ichtiar Baru van Hoeve, 2005), 94. 
oleh komunitas muslim di Indonesiakhususnya di Pondok Pesantren Sunan Pandanaran-dengan istilah khatm al-Qur'ān. Secara terminologi, khatm al-Qur'ān berarti "tamat atau selesai membaca al-Qur'an". Dalam peristilahan yang lazim dipakai di Indonesia adalah khatm al-Qur'ān. Penyebutan khatm al-Qur'ān ini bermacammacam jenisnya, misalnya: betamat dalam masyarakat Bangka, pelaksanaan khatm alQur'ān beragam sesuai dengan kebutuhan dan tujuan masing-masing.

Khatm al-Qur'ān adalah salah satu media untuk menghadirkan al-Qur'an dengan cara mengkhatamkannya. Tentunya aktivitas semacam ini tidak terlepas dari adanya pemaknaan komunitas muslim dan dukungan ayat-ayat al-Qur'an maupun hadis Nabi saw. yang mendorong seseorang untuk mengkhatamkan al-Qur'an serta motif-motif tertentu yang menyemangati rutinitas tersebut. Adanya keutamaan-keutamaan yang akan didapat bagi orang yang mengkhatamkan alQur'an ini sangat memotivasi para pengkhatam al-Qur'an.

Tradisi mengkhatamkan al-Qur'an sudah ada sejak masa Nabi Muhammad saw. berdasarkan hadis-hadis tentang khatm alQur'ān. Salah satu hadis yang memperkuat amalan khatm al-Qur'ān ini antara lain:

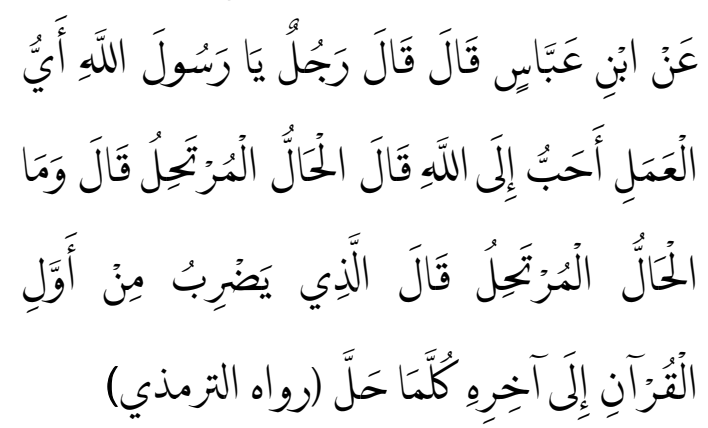

Artinya: Dari Ibnu Abbas ra, beliau mengatakan ada seseorang yang bertanya kepada Rasulullah saw., "Wahai Rasulullah, amalan apakah yang paling dicintai Allah?" Beliau menjawab, "Al-hal wal murtahal." Orang ini bertanya lagi, "Apa itu al-hāl wa al-murtahal, wahai Rasulullah?" Beliau menjawab, "Yaitu yang membaca al-Qur'an dari awal hingga akhir. Setiap kali selesai ia mengulanginya lagi dari awal." (HR. al-Tirmidhī). ${ }^{17}$

Dari hadis di atas tampak bahwa Rasulullah sangat menganjurkan umatnya agar selalu mengkhatamkan al-Qur'an, yakni dengan membaca al-Qur'an dari awal hingga akhir dan mengulanginya lagi dari awal hingga akhir. Arti penting dari aktivitas ini menunjukkan betapa Rasulullah menganjurkan umatnya untuk senantiasa menghadirkan al-Qur'an dalam kehidupan sehari-hari dengan cara mengkhatamkan alQur'an secara berulang-ulang. Tradisi inilah kemudian yang setidaknya dapat dijadikan alasan mengapa khatm al-Qur'ān bagi umat Islam dianggap sebagai amalan yang paling dicintai Allah, bahkan khatm al-Qur'ān diumpamakan dengan harta rampasan perang (ghanimah), sebagaimana hadis:

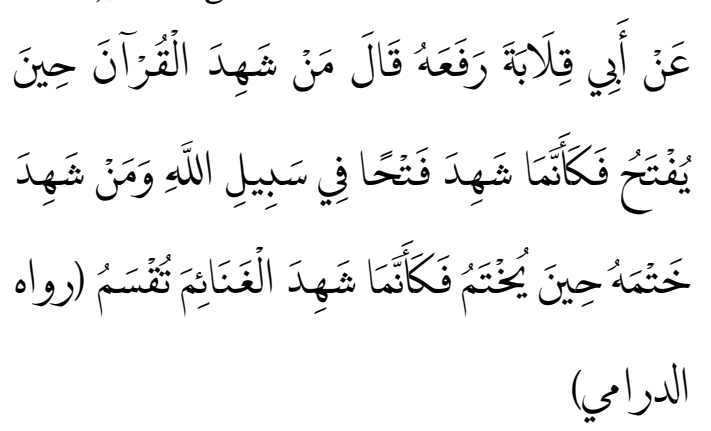

Artinya: Dari Abū Qilābah, Rasulullah saw. mengatakan, "Barangsiapa yang menyaksikan (mengikuti) bacaan AlQur'an ketika dibuka (dimulai), maka seakan-akan ia mengikuti kemenangan

17 Jāmi' al-Huqūq Maḩūzah Lisyirkat alBaramij al-Islāmiyah al-Duliyah, Sunan al-Darimī (CD Mausu'ah al-Ḥadīth, 1998). 
(futuh) fi sabilillah. Dan barangsiapa yang mengikuti pengkhataman AlQur'an maka seakan-akan ia mengikuti pembagian ghanimah." (HR. al-

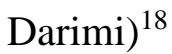

Hadis di atas menunjukkan bahwa budaya mengkhatamkan al-Qur'an diperumpamakan dengan berjuang di jalan Allah ( $f i$ sabilillah)dan mendapatkan harta rampasan perang (ghanimah) yang dapat dinikmati secara bersama-sama. Ghanimah adalah harta yang diperoleh dengan mengorbankan jiwa dan raga karena untuk mendapatkannya harus berperang sampai titik darah penghabisan. Jadi tidaklah heran jika kemudian bagi sebagian umat muslim, khatm al-Qur'ān dianggap sebagai ghanimah, buah hasil dari kerja keras tanpa mengenal lelah yang harus dinikmati, seperti halnya aktivitas mengkhatamkan al-Qur'an dilakukan dengan kerja keras agar dapat menikmati jerih payah yang selama ini diperjuangkan. Perumpamaan khatm al-Qur'ān dengan harta ghanimah inilah menjadi dasar kuat mengapa budaya ini masih bertahan di komunitas umat Islam.

\section{Varian Khatm Al-Qur'ān di PPSPA}

Di PPSPA, istilah khatm al-Qur'ān merujuk kepada proses setelah tamat atau selesai membaca al-Qur'an. Aktivitas khatm al-Qur'ān biasanya dilaksanakan dengan beberapa varian waktu, di antaranya: aktivitas mingguan, seperti Sema'an untuk latihan; aktivitas bulanan, seperti: Sema'an al-Qur'an jelang kegiatan Mujahadah Kamis Wage; aktivitas tahunan, seperti: Majelis khatm alQur'ān dan Tirakatan. ${ }^{19}$ Berikut ini beberapa

18 Jāmi' al-Huqūq Maḥfūzah Lisyirkat alBaramij al-Islāmiyah al-Duliyah, Sunan al-Darimī (CD Mausu'ah al-Hadīth, 1998).

${ }^{19}$ Tirakatan bermakna menahan hawa nafsu dan mengasingkan diri ke tempat yang sunyi. Kamus Besar Bahasa Indonesia, "KBBI Daring Kemdikbud." varian khatm al-Qur'ān di PPSPA berserta fungsinya.

\section{Khatm Al-Qur'ān sebagai Penutup Sema'an Al-Qur'an}

Kata Sema'an diambil dari Bahasa Arab sami'a-yasma'u-sima'an yang berarti "mendengarkan". Kata tersebut dipahami sebagai kegiatan mendengarkan bacaan ayatayat suci al-Qur'an dengan tujuan ingin mendapatkan berkah dari bacaan al-Qur'an tersebut, terutama bagi yang khusyu' mendengarkannya.

Sema'an sendiri adalah prosesi simakmenyimak yang biasa dilakukan para penghafal Al-Qur'an untuk menjaga hafalannya, kegiatan ini dilakukan minimal oleh dua orang, satu orang membaca alQur'an dan yang lainnya menyimak. Bisa juga dilakukan secara bi al-jama'ah (bersama-sama), satu orang membaca dan jama'ah lain menyimak secara bersama-sama. Selain untuk menjaga hafalan, khususnya bagi penghafal al-Qur'an di lingkungan pondok pesantren, Sema'an juga dilakukan untuk mempersembahkan barakah pembacaan alQur'an kepada seseorang, semisal orang yang telah wafat. Dalam hal ini sering kita jumpai Sema'an dalam peringatan khaul (setahun meninggalnya seseorang). Sema'an ini biasanya diakhiri dengan khatm al-Qur'ān berupa pembacaan tahlil dan do'a khatm alQur'ān yang dipersembahkan untuk yang telah wafat tersebut. ${ }^{20}$

Sema'an al-Qur'an di PPSPA menjadi tradisi bulanan setiap sebelum hari Mujahadah Kamis Wage. Pembacaan alQur'an bi al-ghaib (tanpa melihat teks) 30 juz ini khusus dihadiahkan untuk alm. Jauharoh binti KH Munawwir, istri dari KH Mufid Mas'ud yang dimakamkan tepat pada hari

\footnotetext{
${ }^{20}$ Sriyati Dwi Astuti, Wawancara, July 2, 2018.
} 
Kamis Wage setelah salat Ashar tanggal 21 Sya'ban 1419/08 Desember 1998. Sema'an biasanya diakhiri dengan tahlil dan do'a khatm al-Qur'ān. ${ }^{21}$ Di PPSPA, kegiatan ini dapat pula dikatakan dengan mujahadah akbar yang diselenggarakan setiap 35 hari sekali (Baca Jawa: selapanan), tepatnya setiap hari Kamis Wage setelah salat Ashar. Acara ini diikuti oleh hampir seluruh santri PPSPA serta ratusan tamu yang hadir. Mujahadah ini menjadi momen yang dinantikan oleh masyarakat karena di dalamnya terdapat dua agenda besar, khatm al-Qur'ān dan pengajian Mujahadah Kamis Wage.

\section{Khatm Al-Qur'ān sebagai Penutup Muqaddaman}

Berbeda dengan Sema'an, muqaddaman lebih bersifat pembacaan Al-Qur'an yang dilakukan bersama-sama, di mana juz pertama hingga juz 30 dibaca oleh orang yang berbeda namun dalam satu majelis. Jadi sebelum dibuka majelis muqaddaman, para peserta diberi jatah bagian juz yang hendak dibaca. Baru kemudian secara bersama-sama si A, misalnya membaca juz sekian dan si B membaca juz yang lainnya dan seterusnya. Satu hal lagi yang membedakan Sema'an dan muqaddaman adalah dalam Sema'an, pembacaan al-Qur'an tanpa teks al-Qur'an, sementara Muqaddaman merupakan pembacaan al-Qur'an dengan teks, yakni membaca seperti biasa. Namun prosesi khatm al-Qur'ān dalam muqaddaman hampir sama dengan Sema'an, yakni: dimulai dengan pembacaan surah al-Fatihah, peserta membaca bagian juz masing-masing dan

21 Buku Pegangan Pengajian Dan Mujahadah Kamis Wage, Cetakan ke-IV (Yogyakarta: Pondok Pesantren Sunan Pandanaran, 2007). Suara Pandanaran, September 2006. Suara Pandanaran, Desember 2007. diakhiri dengan kegiatan khatm al-Qur'ān berupa tahlil dan do'a khatm al-Qur'ān. ${ }^{22}$

Dilihat dari tujuannya, muqaddaman bisa bermakna lebih luas. Ditilik dari segi bahasa, muqaddaman berarti persembahan. Asal kata dari qaddama-yuqaddimu. Tujuan diadakannya muqaddaman ini bisa bermacam-macam, di antaranya: muqaddaman untuk orang yang telah wafat, kesuksesan usaha yang akan dirintis pertama kali, pembangunan masjid, rumah, pernikahan dan hajat-hajat lain. Hal yang diharapkan dari pembacaan muqaddaman ini agar hajat-hajat yang direncanakan akan berjalan dan berakhir dengan sukses.

\section{Khatm Al-Qur'ān sebagai Penutup Majelis Khatm Al-Qur'ān Akbar \\ Di PPSPA, kegiatan ini biasanya} dilaksanakan setiap tahun sekali. Pada setiap tahunnya, pelaksanaan difokuskan pada malam 27 Sya'ban. Khatm al-Qur'ān Akbar merupakan puncak perayaan kalangan santri yang berhasil mengkhatamkan al-Qur'an (bi al-gaib dan bi al-nazar). Acara ini dihadiri ribuan orang baik dari kalangan ulama, umara', wali santri, maupun para alumni. Momen ini menjadi ajang bertemu dan berkumpulnya para alumni yang sudah tersebar ke seluruh pelosok Indonesia. Tidak hanya itu, momen ini, terutama bagi santri Madrasah Tsanawiyyah (MTs) dan Madrasah Aliyah (MA) PPSPA, menjadi ajang untuk unjuk kebolehan kegiatan ekstra kurikuler yang diikuti di sekolah masing-masing, seperti Drum band. Sementara itu, seminarseminar dan kegiatan bakti sosial juga yang mengiringi acara khataman akbar ini, misalnya khitanan massal, bakti sosial membagi-bagikan pakaian pantas pakai untuk yang membutuhkan dan lain-lain.

\footnotetext{
${ }^{22}$ Sriyati Dwi Astuti, Wawancara, Mei 2018.
} 


\section{Khatm Al-Qur'ān sebagai Penutup Tirakatan}

Tirakatan dalam kamus Besar bahasa Indonesia diartikan dengan menahan hawa nafsu (seperti berpuasa, berpantang); bisa juga diartikan dengan mengasingkan diri ke tempat yang sunyi (di gunung dan sebagainya). ${ }^{23}$ Aktivitas Tirakatan dilaksanakan sebanyak 40 hari, oleh karenanya sering juga disebut dengan patang puluhan (40-an). Di PPSPA, tirakatan adalah kegiatan yang khusus diperuntukkan untuk para santri yang sudah menyelesaikan hafalan 30 juz, yakni pembacaan al-Qur'an yang dilakukan selama 40 hari berturut-turut. Menurut Miftahul Karim, bagi santri yang mengikuti acara tersebut, pada setiap harinya diwajibkan mengkhatamkan al-Qur'an bi al-hifzi dalam kondisi berpuasa. Dan jika sebelum 40 hari pembacaan al-Qur'an tersebut terputus, maka harus mengulangi dari awal lagi. Tirakatan ini menjadi spesial karena tidak semua santri bisa mengikutinya. Menurut Karim, pada masa KH Mufid Mas'ud, santri ditunjuk untuk oleh beliau karena dianggap sudah mampu. Akan tetapi pada masa KH. Mu'tasim Billah, santri mengajukan diri. Lalu pihak ndalem (sebutan untuk keluarga Pengasuh PPSPA) melakukan tes seleksi. Apabila dianggap mampu baru diizinkan untuk riyāạah. ${ }^{24}$

Sejauh informasi diperoleh dari wawancara informan dengan cara mencoba mengkonfirmasi mengenai argumentasi mengapa harus dilakukan selama 40 hari. Menurut Karim, Nabi Musa as menyepi di bukit Tursina selama 40 hari, Nabi Yunus berada dalam perut ikan selama 40 hari, Nabi Nuh as membuat perahu selama 40 hari. Inilah kemudian yang menjadi alasan

23 Kamus Besar Bahasa Indonesia, "KBBI Daring Kemdikbud.”

${ }^{24}$ KH. Mu’tasim Billah, Wawancara, Mei 2008. mengapa para ulama salaf menyimpulkan kalau tirakatan dilakukan selama 40 hari. ${ }^{25}$

Kegiatan ini membutuhkan konsentrasi penuh. Maka biasanya para santri yang ditirakatkan ini ditempatkan di tempat khusus. Pada acara ini, KH Mufid Mas'ud mengharuskan santri untuk menetap sementara dan melaksanakannya di Mbayat, Klaten, dekat makam Sunan Pandanaran. Kegiatan ini bisa dikatakan juga semacam Kuliah Kerja Nyata (KKN) bagi mahasiswa tingkat akhir. Pada kegiatan ini, selain santri disyaratkan telah hafal al-Qur'an 30 juz dengan baik juga kekuatan fisik dan spiritual santri amat dibutuhkan. Karena selama 41 hari tersebut kegiatan yang dilakukan seharian penuh melibatkan konsentrasi penuh, kesabaran, ketekunan, dan ketahanan fisik yang kuat. Ada pun biaya selama menjalani tirakatan sepenuhnya ditanggung oleh pihak PPSPA. ${ }^{26}$

\section{Ekspresi Mendalam: Tafsir Atas Budaya Khatm Al-Qur'ān di PPSPA}

Khatm Al-Qur'ān di Pondok Pesantren Sunan Pandanaran (PPSPA), secara formal dilaksanakan pada tahun 1976 setelah berdirinya pada tanggal 20 Desember 1975. Pada awal mulanya, khatm al-Qur'ān di PPSPA diselenggarakan sangat sederhana hanya dengan tasyakuran do'a khatm alQur'ān tanpa acara-acara pendukung lain. Pada perkembangan selanjutnya, khatm alQur'ān-pun dilaksanakan setiap 35 hari (selapanan) bersama dengan Mujahadah Kamis Wage. Acara ini diselenggarakan dalam rangka untuk memperingati hari wafatnya Ibu Jauharoh yang meninggal pada

\footnotetext{
${ }^{25}$ Miftahul Karim, Wawancara, April 30, 2008.

${ }^{26}$ Sriyati Dwi Astuti, Wawancara, Mei 2018.
} 
hari Kamis Wage 08 Desember $1998 .^{27}$ Seiring dengan perkembangan PPSPA, khatm al-Qur'ān diselenggarakan bersamaan dengan acara-acara lain, seperti: sunatan massal yang diikuti warga sekitar, bakti sosial atau pembagian dana dari pesantren untuk masyarakat sekitar, parade drum band oleh siswa-siswi MTs-MA, bahkan sejak tahun 2006 untuk pertama kalinya diadakan halaqah Nasional dengan tema "Pengembangan Pembelajaran al-Qur'an di Pondok Pesantren" dan pada tahun 2007 dengan tema "Perumusan Kurikulum Pendidikan Pasca Tahfizh". 28

Khatm al-Qur'ān di PPSPA memiliki banyak pemaknaan dari para komunitasnya. Secara umum, ada beberapa pandangan mengenai khatm al-Qur'ān. Dengan perspektif tafsir kebudayaan, berikut dikemukakan berbagai dimensi penafsiran atas budaya khatm al-Qur'ān di PPSPA menurut komunitas muslim yang berinteraksi dalam kegiatan khatm al-Qur'ān.

\section{Dimensi Spiritual Khatm Al-Qur'ān: Wujud Komunikasi dan Ekspresi}

Pada awalnya - secara umum, khatm al-Qur'ān dimaknai sebagai salah satu bentuk media ibadah seorang hamba dalam rangka mendekatkan diri kepada sang Khaliq melalui pengkhataman ayat-ayat suci al-Qur'an, baik dilakukan secara individu maupun kolektif. Namun pada perkembangan selanjutnya, khatm al-Qur'ān mengalami pergeseran maknanya, tidak hanya dimaknai sebatas rutinitas menamatkan membaca al-Qur'an kemudian ditutup dengan doa khatm alQur'ān. Tetapi lebih dari itu, berdasarkan pengetahuan dan pengalaman individu yang

27 Buku Pegangan Pengajian Dan Mujahadah Kamis Wage.

${ }^{28}$ September 2006. berbeda-beda, khatm al-Qur'ān dimaknai secara beragam oleh para komunitasnya tidak hanya sebagai media ibadah tapi juga dimaknai sebagai media-media lain.

Khatm al-Qur'ān bagi mayoritas komunitas muslim di PPSPA bisa dimaknai sebagai wujud tasyakuran. Meski sebenarnya, secara bahasa khatm al-Qur'ān dan tasyakuran adalah dua hal yang memiliki makna berbeda. Tetapi keduanya, secara implisit, memiliki keterkaitan yang sangat erat. Adanya khatm al-Qur'ān adalah bentuk terima kasih seorang hamba terhadap sang Pencipta yang dikomunikasikan lewat media membaca, menghafal bahkan selanjutnya mengkhatamkan al-Qur'an. Begitu pula dengan tasyakuran adalah sebuah wujud ekspresi terima kasih yang ditampakkan akan tercapainya atau terkabulnya suatu maksud yang selama ini dicita-citakan, direncanakan dan diperjuangkan. Oleh karenanya, khatm alQur'ān adalah dalam rangka tasyakuran atas cita-cita, rencana, dan perjuangan mengkhatamkan al-Qur'an yang telah dilalui dalam kurun waktu yang mungkin sangat panjang - tergantung kemampuan masingmasing individu. Itulah kemudian mengapa dapat dikatakan bahwa khatm al-Qur'ān bisa dimaknai sebagai wujud komunikasi seorang hamba terhadap Tuhannya sekaligus sebagai wujud ekspresi atas cita-cita, rencana, dan perjuangannya.

Pemaknaan tentang khatm al-Qur'ān sebagai wujud komunikasi dan ekspresi ini didukung oleh beberapa sumber data penelitian yang pernah dilakukan, misalnya yang disampaikan Syarifudin dan Hadi Mansur (pengurus Inti PPSPA) orang yang biasa mengkhatamkan al-Qur'an sebanyak dua kali dalam sebulan. Menurutnya: "Majelis khatm al-Qur'ān di PPSPA yang diadakan setiap malam 17 Sya'ban sebagai bentuk 
syukur di akhir tahun(tasyakur akhir alsanah). Khatm al-Qur'ān dimaksudkan pula sebagai arena wisuda bagi santri yang khatam sesuai tingkatan atau jenisnya dengan dipanjatkan do'a oleh para Kyai yang hadir." Khatm al-Qur'ān adalah proses membaca alQur'an dari juz 1 sampai 30. Acara khatm alQur'ān yang diselenggarakan PPSPA dalam rangka memohonkan do'a untuk santri-santri yang telah selesai menghafal dari juz 1 sampai 30 dan telah disimak atau diuji di hadapan para Kyai." 29

Dari pendapat di atas - secara eksplisit, dipahami bahwa khatm al-Qur'ān adalah bagian dari rasa syukur kepada Allah swt., sekaligus menjadi medan perjuangan (arena) bagi para pengkhatam al-Qur'an serta menjadi media komunikasi dalam rangka memohonkan do'a bagi santri yang telah mengkhatamkan al-Qur'an.

\section{Dimensi Individual Khatm Al-Qur'ān: Antara Prestasi dan Prestise}

Motivasi adalah faktor pendorong bahkan menjadi bagian terpenting untuk mewujudkan prestasi dan prestise. Dalam hal ini, khatm al-Qur'ān di PPSPA telah menjadi motivasi para santri meraih prestasi atau bahkan prestise. Untuk mewujudkannya, santri harus lebih giat menghafal (bi al-ghaib) atau menamatkan membaca al-Qur'an (bi alNazar) sesuai target dari individu masingmasing atau pun dari pihak pengurus pesantren. Motivasi ini tidak lahir begitu saja, faktor internal dan eksternal turut menjadi pendukung atau bahkan penghambat lahirnya sebuah tindakan. Namun biasanya, faktor eksternal berupa tuntutan keluarga, sekolah, bahkan kebijakan yang diambil oleh pihak pengurus justru terkadang memaksa budaya disiplin lahir dari seorang individu menjadi

\footnotetext{
${ }^{29}$ Hadi Mansur, Wawancara, July 5, 2008.
}

lebih dominan dalam mendukung kesuksesan santri dalam mengkhatamkan al-Qur'an.

$$
\text { Khatm al-Qur'ān di PPSPA }
$$
terselenggara tidak hanya peran individu (santri) dalam mengkhatamkan al-Qur'an, tetapi juga melibatkan banyak unsur: santri, wali santri, keluarga ndalem, dan para para pengurus di PPSPA. Mereka bahu-membahu untuk mewujudkan terselenggaranya acara khatm al-Qur'ān. Kerja sama yang dijalin dengan berbagai organisasi, instansi, dan para alumni adalah menjadi bagian dari upaya mewujudkan penyelenggaraan khatm alQur'ān di PPSPA. Tidak hanya sebatas terselenggaranya acara, tetapi juga suksesnya acara menjadi bagian terpenting untuk keberlangsungan pesantren di masa yang akan datang.

Ukuran kesuksesan sebuah penyelenggaraan khatm al-Qur'ān di PPSPA memang tidak ada standar yang pasti. Namun, paling tidak bisa diukur dari beberapa tolok ukur, di antaranya: banyaknya jumlah peserta (santri) yang mengkhatamkan al-Qur'an, banyaknya acara-acara pendukung (semisal: bakti sosial, seminar nasional, sunatan masal, pawai drum band dsb), banyaknya kehadiran para tamu undangan yang hadir, dan masih banyak lagi unsur-unsur lain yang menjadi tolok ukur keberhasilan sebuah acara. Ini semua, tentunya, memiliki maksud dan tujuan. Paling tidak maksudnya mempertahankan kredibilitas pesantren di mata masyarakat dan tujuannya menyiarkan pesantren ke dunia luar adalah bagian dari prestasi yang akan dicapai oleh PPSPA.

Pemaknaan khatm al-Qur'ān sebagai prestasi ini didukung oleh banyak data yang saya temukan. Beberapa di antaranya adalah informasi dari Ansori Maksum lebih memahami Khatm Al-Qur'ān sebagai aktivitas penting yang menjadi tolok ukur 
kesempurnaan dan kesuksesan sebuah pesantren. Ia menuturkan: 'Khatm al-Qur'ān terlihat sepintas kurang berguna, namun sesungguhnya itu semua sangat penting dan diperlukan sekali untuk mencapai kesempurnaan dalam kesuksesan pesantren." ${ }^{30}$ Menurut Munir Tadho dan Wahyu Kusuma Islam, khatm al-Qur'ān menjadi motivasi yang dapat mendorong santri yang menghafal untuk lebih giat lagi dalam menghafalnya, bagi yang belum menghafal, khatm al-Qur'ān dapat mendorong santri untuk menghafalnya."31 Tidak hanya sebatas itu, acara khatm alQur'ān sendiri mengajak santri untuk selalu membaca atau bahkan menghayati dan mengamalkannya pada kehidupan. Khatm alQur'ān juga dijadikan memotivasi untuk berlomba-lomba dalam menumbuhkan rasa semangat untuk terus maju. Selain itu, acara khatm al-Qur'ān sendiri dianggap mampu memberikan pencerahan pada setiap pembacanya.

Selain prestasi, sebenarnya ada agenda lain-menurut hemat penulis-yang terselubung dari acara khatm al-Qur'ān, yakni prestise. Keinginan individu (santri) atau kolektif (pesantren) untuk dihargai, dihormati, dan dibanggakan oleh teman guru, keluarga atau masyarakat adalah bagian dari keikutsertaan mereka pada acara khatm alQur'ān. Menurut penulis hal ini wajar, dalam kehidupan bermasyarakat, meningkatnya status sosial seseorang di sebuah masyarakat menjadi bagian penting untuk sebuah eksistensi. Pemaknaan khatm al-Qur'ān sebagai sebuah prestise ini berdasarkan pemaknaan yang disampaikan oleh Ansori Maksum memaknai khatm al-Qur'ān sarana

\footnotetext{
${ }^{30}$ Ansori Maksum, Wawancara, Mei 2008.

31 Munir Tadho and Wahyu Kusuma Islam, Wawancara, Mei 2008.
}

untuk lebih dipandang tinggi atau dihormati, sarana mendapatkan penghargaan kemampuan, dan sarana mencapai sukses dunia-akhirat. Menurutnya, sarana-sarana tersebut tentunya akan menimbulkan pengaruh berbeda-beda dalam kesehariannya. Siapa yang paling baik dan benar tujuan khatm al-Qur'ān, maka semakin baik dan benar perilaku dan akhlaknya. ${ }^{32}$

Dengan demikian, prestasi dan prestise adalah dua hal yang saling berkaitan. Dalam kehidupan berkeluarga, bermasyarakat, berbangsa dan bernegara keduanya menjadi bagian yang diharapkan bahkan dituntut oleh setiap individu. Prestasi mengharapkan adanya prestise dari sebuah pencapaian yang dihasilkan, begitu pula prestise menuntut adanya prestasi yang dicapai.

\section{Dimensi Sosial Khatm Al-Qur'ān: Ajang Silaturahmi dan Bisnis}

Sebagai salah satu aktivitas living Qur'an, khatm al-Qur'ān selain telah menjadi salah satu media untuk mendekatkan diri kepada Allah SWT., juga sekaligus media memperkenalkan PPSPA ke dunia luar. Oleh karenanya, khatm al-Qur'ān di PPSPA banyak mendapat respons yang positif dan dukungan kuat dari komunitas muslim di sana.

Acara khatm al-Qur'ān telah menghadirkan banyak orang dari berbagai penjuru. Secara sosiologis, khatm al-Qur'ān dapat dimaknai sebagai ajang merekatkan hubungan sosial yang selama ini mungkin terputus. Letak geografis yang berjauhan dan aktivitas sehari-hari yang padat menjadi sekian penyebab renggangnya komunikasi. Dengan adanya khatm al-Qur'ān, sekat-sekat yang renggang itu dapat dirapatkan kembali. Sebagaimana diungkapkan oleh Wahyu

\footnotetext{
${ }^{32}$ Ansori Maksum, Wawancara, June 3, 2008.
} 
Kusuma Islam, khatm al-Qur'ān di PPSPA menjadi wadah silaturahmi bagi siapa saja warga sekitar, wali santri, para pendatang terlebih bagi para santri dan keluarga PPSPA. Selain sebagai media penghubung dan pengenal khatm al-Qur'ān sendiri sangat berfungsi untuk pendekatan diri kita kepadaNya. Khususnya bagi orang-orang di luar sana yang memerlukan wadah semacam itu. Sekaligus sebagai penghubung tali silaturahmi kita antara pondok dan pihak luar."

Acara khatm al-Qur'ān telah menghadirkan banyak pengunjung dari kalangan umat Islam. Ribuan jamaah yang hadir pada acara tersebut, tentunya, memberikan dampak ekonomis bagi masyarakat sekitar PPSPA. Para pedagang, para juru parkir, para sopir adalah bagian komunitas yang mengambil keuntungan dari keramaian tersebut. Mereka mungkin tidak mengikuti proses khatm al-Qur'ān atau bahkan mungkin juga tidak paham apa makna khatm al-Qur'ān? Dalam benak dan pikiran mereka adalah yang penting setiap ada acara yang menghadirkan keramaian maka di situlah ada sumber penghasilan. Oleh karenanya, wajar jika sebagian orang memaknai khatm al-Qur'ān sebagai ajang bisnis. Pemaknaan "bisnis" ini bisa sangat meluas, bisa jadi khatm al-Qur'ānnya yang dijadikan ajang "bisnis pesantren" atau ajang bisnis komunitas di luar pesantren. Pemaknaan ini tergantung dari sudut pandang siapa? Seperti disampaikan Syarifuddin: 'Khatm al-Qur'ān adalah sarana meningkatkan ekonomi masyarakat. Banyak perdagangan, masyarakat sekitar ikut berjualan, jadi tempat parkir, halaman disewakan untuk para pedagang, sopir angkot ramai penumpang, dan khitanan massal gratis." 33

Dari pemaparan di atas, dapat dipahami bahwa terdapat banyak ragam fenomena pemaknaan khatm al-Qur'ān oleh komunitas muslim di PPSPA. Perbedaan latar belakang pendidikan, sosial, budaya, baik pengalaman, situasi dan kondisi dan seterusnya menyebabkan pemaknaan terhadap khatm alQur'ān menjadi beragam. Khatm al-Qur'ān yang makna utamanya adalah proses mengkhatamkan al-Qur'an kemudian dimaknai beragam oleh para komunitas muslim di PPSPA. Khatm al-Qur'ān bisa dimaknai sebagai wujud komunikasi dan ekspresi, bisa juga antara prestasi dan prestise, dan bahkan ajang silaturahmi dan bisnis. Penafsiran yang beragam ini mengisyaratkan bahwa tahtiman memiliki banyak dimensi: spiritual, individu, dan sosial. Hubungan ketiga dimensi ini menggambarkan bahwa khatm al-Qur'ān merupakan ekspresi dalam wujud komunikasi terhadap sang Khaliq sekaligus ekspresi rasa syukur kepada-Nya. Dimensi individu mengekspresikan sebagai prestasi sekaligus prestise bagi setiap pengkhatamnya, dan dimensi sosial sebagai ajang silatuhami dan bisnis bagi komunitas yang ada dalam aktivitas tersebut.

\section{Simpulan}

Khatm al-Qur'ān di PPSPA tidak hanya dipahami sebagai aktivitas menamatkan membaca ataupun menghafalkan al-Qur'an. Dalam perkembangannya, khatm al-Qur'ān hadir dengan berbagai varian sesuai kebutuhannya, meliputi: khatm al-Qur'ān sebagai penutup semaa'an al-Qur'an, khatm al-Qur'ān sebagai penutup muqaddaman, khatm al-Qur'ān sebagai penutup Mujahadah Kamis Wage, khatm al-Qur'ān sebagai

\footnotetext{
${ }^{33}$ Syarifuddin, Wawancara, Mei 2008.
} 
penutup dalam majelis khatm al-Qur'ān dan khatm al-Qur'ān sebagai penutup dalam tirakatan.

Khatm al-Qur'ān di PPSPA tidak hanya dimaknai sebagai proses penutupan dalam aktivitas Khatm al-Qur'ān, tetapi berdasarkan perilaku budaya komunitasnya bisa ditafsirkan beragam. Secara dimensi spiritual, khatm al-Qur'ān dapat ditafsirkan sebagai wujud komunikasi dan ekspresi bagi setiap pembaca al-Qur'an terhadap Tuhan-Nya, secara dimensi individual, khatm al-Qur'ān dapat ditafsirkan sebagai prestasi dan prestise bagi para pengkhatamnya, dan secara sosial, khatm al-Qur'ān dapat ditafsirkan sebagai ajang silaturahmi bagi komunitas muslim di sekitar PPSPA dan sekaligus ajang bisnis bagi setiap orang yang memiliki kepentingan ekonomi dalam kegiatan tersebut.

\section{Pustaka Acuan}

Abdullah Saeed. The Qur'an: An Introduction. London and New York: Routledge, 2008.

Agus Salim. Teori Dan Paradigma Penelitian

Sosial; Buku Sumber Untuk Penelitian

Kualitatif. Cetakan Kedua. Yogyakarta:

Tiara Wacana, 2006.

Ahmad Warson Munawwir. Al-Munawwir:

Kamus Arab-Indonesia. Surabaya:

Pustaka Progresif, 1997.

Al-Dzahabi. Al-Tafsir Wa Al-Mufassirun. 1st ed. Kairo: dar al-Kutub al-Haditsat, 1991.

Al-Munjid. Al-Munjid Al-Abjadi. Cet. 37. Beirut: Dar al-Masyriq, 1998.

Ansori Maksum. Wawancara, Mei 2008. . Wawancara, June 3, 2008.

Buku Pegangan Pengajian Dan Mujahadah Kamis Wage. Cetakan ke-IV. Yogyakarta: Pondok Pesantren Sunan Pandanaran, 2007.
Chaerul Mundzir. "Nilai-Nilai Sosial Dalam Tradisi Mappanre Temme Di Kecamatan Tanete Rilau, Kabupaten Barru." Rihlah: Jurnal Sejarah Dan Kebudayaan 1, no. 2 (2014): 69-80.

Clifford Geertz. Tafsir Kebudayaan. Translated by Francisco Budi Hardiman. Yogyakarta: Kanisius, 1992. Gusnanda. "Katam Kaji: Resepsi Al-Qur'an Masyarakat Pauh Kamang Mudiak Kabupaten Agam." Mashdar: Jurnal Studi Qur'an Dan Hadis 1, no. 1 (2019): 67-82.

Hadi Mansur. Wawancara, July 5, 2008.

Heddy Shri Ahimsa-Putra. "Fenomenologi Agama: Pendekatan Fenomenologi Untuk Memahami Agama." Walisongo 20, no. 2 (2012): 271-304.

Ibn Manzhur. Lisan Al-'Arab. Beirut: Dar Shadir, n.d.

Jami' Al-Huquq Mahfuzah Lisyirkat AlBaramij Al-Islamiyah Al-Duliyah. Sunan Al-Tirmizi. CD Mausu'ah alHadis, 1998.

Jami' Al-Huquq Mahfuzah Lisyirkat AlBaramij Al-Islamiyah Al-Duliyah. Sunan Al-Darimi. CD Mausu'ah alHadis, 1998.

KH. Mu'tasim Billah. Wawancara, Mei 2008. Miftahul Karim. Wawancara, April 30, 2008. Munir Tadho, and Wahyu Kusuma Islam. Wawancara, Mei 2008.

“Nama 'Sunan Pandanaran' diambil Dari Silsilah Keturunan KH. Mufid Mas'ud. Beliau Adalah Keturunan Ke-10 Dari Ki Ageng Sunan Pandanaran, Salah Satu Santri Dari Sunan Kalijaga." Suara Pandanaran; Majalah Pesantren. I edition, September 2005. 